\title{
Despedida al profesor Florian Śmieja
}

El día 4 de septiembre de 2019 en la ciudad canadiense de Mississauga falleció Florian Śmieja, eminente hispanista, reconocido poeta, notable traductor, insigne editor y, ante todo, un hombre de una gran sabiduría e infinita sensibilidad.

$* * *$

Para aquel día el profesor Florian Śmieja había trazado, sin embargo, planes diferentes. Dos semanas antes había escrito a Piotr Sawicki: "he perdido la movilidad y apenas puedo caminar, sin embargo el 4 de septiembre tengo una cita con el cardiólogo para consultar una eventual cirugía de corazón. Así que debo resistir. Sigo escribiendo poemillas, pero sin convicción, la apatía me está venciendo". Y más adelante, con un entusiasmo evidente, añadía: "he vuelto a ser abuelo, ya que ayer mi hijo menor tuvo una hija"1. Cuando nos llegó la noticia de la muerte del Profesor, rodeado por su familia, recordamos las estrofas del inmortal poemario de Jorge Manrique: „Assí, con tal entender, / todos sentidos humanos / conservados, / cercado de su mujer, / y de sus hijos e hermanos / e criados,/ dio el alma a quien se la dio / (el cual la ponga en el cielo / en su gloria) / que aunque la vida perdió, / dexónos harto consuelo/ su memoria"2.

$$
* * *
$$

Florian Śmieja fue testigo y protagonista de la complicada historia polaca del siglo XX: nacido el 22 de agosto de 1925 en Kończyce, en la zona de Alta Silesia donde cuatro años antes de su nacimiento se había trazado la frontera entre Polonia y Alemania, vivió la atmósfera de un país novel, experimentó en 1939 el ataque de la Alemania nazi que le obligó a huir al Este; dos semanas más tarde, tras la agresión de la Rusia estalinista, prefirió volver a casa. En 1940 fue llevado a realizar trabajos forzados a Macklenburgo. Más tarde,

1 “[S]traciłem mobilność i ledwo kuśtykam, a 4 września mam kardiologa na rozmowę o ewentualnej operacji serca. Muszę więc dotrwać. Piszę jeszcze wierszyki bez przekonania, apatia bierze górę. [...] Zostałem dziadkiem raz jeszcze, gdyż wczoraj mojemu młodszemu Synowi urodziła się córka". Facilitado por Piotr Sawicki, la correspondencia privada.

2 J. Manrique, Poesía, Madrid, Cátedra, 1984, pp. 166-167. 
finalizada la guerra, se encontró en Bélgica donde, tras la entrada de las tropas aliadas, se presentó voluntario al ejército polaco y formó parte de la célebre brigada del general Maczek. Acabada la contienda, no volvió a Polonia y siguió la suerte de los cientos de miles de exiliados polacos. Obtuvo el bachillerato en un colegio polaco en Escocia, finalizó los estudios en Irlanda, empezó a trabajar en la School of Slavonic and East European Studies del University College London. En el londinense King's College se licenció en 1955 y se doctoró en 1962, con una tesis escrita bajo la dirección del célebre hispanista británico Alexander A. Parker. Entre 1963 y 1969 trabajó en la Universidad de Nottingham y en 1969 fijó su residencia en Canadá. Allí dirigió la sección española del Department of Modern Languages and Literatures de la Universidad de Western Ontario durante más de veinte años, hasta su jubilación en 1991.

Siempre centró su interés académico en los temas comparativos: mostró las filiaciones polacas con la literatura española e iberoamericana, editó un manuscrito sobre San Casimiro atribuido a Agustín Moreto, documentó la recepción de dramas españoles en Polonia, rescató la primera traducción polaca de La vida es sueño. Asimismo colaboró con la prensa polaca del exilio y fue cofundador y editor de algunas revistas culturales que se conviertieron en tribuna del llamado "grupo de poetas londinenses", a los que perteneció también Florian Śmieja, quien debutó poéticamente en 1953 con un libro titulado Czuwanie u drzwi, al que siguió una docena más de bellos tomos poéticos. Es autor de numerosas traducciones entre las cuales destaca su versión polaca de Platero y yo de Juan Ramón Jiménez, Tiempo de silencio de Luis Martín-Santos, Los de debajo de Mariano Azuela, las leyendas de Bécquer y la poesía arábigo-andaluza. Preparó varias antologías poéticas, publicó una recopilación de conversaciones con otros poetas y documentó la actividad literaria de los emigrantes polacos.

Tanto la obra literaria como el trabajo académico ha sido y sigue siendo objeto de diversos estudios. Recordemos aquí el tomo de estudios Parabole pamięci. Literacka i translatorska twórczość Floriana Śmieji (2004) preparado por Zbigniew Andres y Jan Wolski; el libro Rzeczywiste $i$ możliwe. Rozmowy z Florianem Śmieja (2005) preparado por Marcin Kurek y Justyna Ziarkowska; el trabajo monográfico Navigare necesse est. Świadectwa pamięci w twórczości literackiej Floriana Śmiei (2015) de Nina Cieślik-Wilk o un estudio que está a punto de publicarse, titulado Poeci „Kontynentów” y preparado por Jerzy Sikora.

$$
* * *
$$

En junio de 1990 Florian Śmieja participó en Varsovia en una reunión de escritores polacos del exilio con los artistas del país y decidió aprovechar la estancia en Polonia para realizar una consulta científica en la biblioteca Ossolineum de Wrocław. Un encuentro con el profesor Piotr Sawicki, en aquel entonces jefe de la sección española del Departamento de Filología 
Románica de la Universidad de Wrocław, tuvo una agradable consecuencia. A partir de aquel momento la Universidad de Wrocław pudo desarrollar una fructífera colaboración científica y didáctica con Florian Śmieja quien, entre 1991 y 1997, impartió clases como profesor visitante de literatura española y de literatura polaca del exilio. En uno de sus ensayos recordaba: "siguió para mí un período espléndido de Wrocław que duró seis años durante los que pudo dar clases a los estudiantes polacos después de décadas de trabajo en Gran Bretaña y Canadá"3.

$* * *$

Florian Śmieja desde el año 2000 fue miembro, primero del Consejo Asesor, luego de Consejo Científico de Estudios Hispánicos asesorándonos siempre en cuantas cuestiones se le demandaban. Le dedicamos primero el volumen VI (1997) en su setenta cumpleaños y más tarde el volumen XXIII (2015) en su noventa cumpleaños y con motivo de la concesión —el 6 de mayo de 2015- del título de doctor honoris causa de la Universidad de Wrocław y asimismo de la Cruz de la Encomienda de la Orden Isabel la Católica otorgada por Felipe VI, Rey de España, y entregada por Agustín Núñez Martínez, embajador del Reino de España en Polonia. En dicho volumen colaboraron varios hispanistas polacos, sobre todo de la Universidad de Wrocław, pero también investigadores de otros centros importantes para el Homenajeado como Marjorie Ratcliffe de University of Western Ontario en London (Canadá) o Terence O'Reilly de University College Cork (Irlanda) donde Florian Śmieja en 1947 inició sus estudios de filología inglesa y española.

En el ámbito académico y humano el profesor Florian Śmieja fue para nosotros un insigne maestro, una persona muy benévola y serena, un hombre de unos conocimientos enormes y de una modestia sobrecogedora que todo se lo debía a su constancia y su disciplina, a su trabajo y su talento. Estamos agradecidos con la fortuna que puso en nuestro camino a Florian Śmieja.

\section{Piotr Sawicki (profesor emérito de Uniwersytet Wrocławski) \\ Justyna Ziarkowska (Uniwersytet Wrocławski)}

3 "[N]astąpił dla mnie wspaniały okres wrocławski trwający sześć lat, w ciągu których mogłem uczyć polskich studentów po dekadach pracy w Anglii i Kanadzie Florian Śmieja”, F. Śmieja, Delta czasu, Katowice, Biblioteka Śląska, 2018, p. 159. 